\title{
ANALISIS KINERJA PERTUMBUHAN LARVA IKAN TAWES (Puntius javanicus) YANG DIBERI PAKAN Daphnia sp. DIKOMBINASI DENGAN VITAMIN D
}

\author{
Agung Sastra Winata ${ }^{1}$, Armen Nainggolan ${ }^{2}$, Firsty Rahmatia ${ }^{3}$ \\ Fakultas Perikanan dan Ilmu Kelautan Universitas Satya Negara Indonesia \\ email:agung.fpik2013@gmail.com
}

\begin{abstract}
ABSTRAK
Penelitian ini bertujuan untuk mengetahui dosis suplementasi vitamin D pada Daphnia sp. untuk peningkatan kualitas larva ikan Tawes dan untuk megetahui pengaruh penambahan vitamin D pada Daphnia sp. terhadap larva ikan Tawes. Data hasil pengamatan (Parameter SR, pertumbuhan larva (panjang dan bobot), dilakukan menggunakan rancangan acak lengkap (RAL) dalam satu faktor dengan lima perlakuan dan tiga ulangan. Perlakuan yang diberikan adalah penambahan vitamin D dengan dosis $0 \mathrm{mg} / \mathrm{l}, 25 \mathrm{mg} / \mathrm{l}, 50 \mathrm{mg} / \mathrm{l}, 75 \mathrm{mg} / \mathrm{l}$, dan $100 \mathrm{mg} / \mathrm{l}$. Hasil penelitian menunjukan dosis vitamin D yang paling efisien yang disuplementasikan pada Daphnia sp. sebagai pakan larva ikan Tawes untuk peningkatan kualitas larva ikan Tawes adalah $25 \mathrm{mg} / \mathrm{l}$. Pengaruh penambahan dosis vitamin D pada Daphnia sp. terhadap larva ikan Tawes dapat diperoleh bahwa dosis $25 \mathrm{mg} / 1$ nilai $\mathrm{SR}=85 \%, \mathrm{Wt}=245,1 \mathrm{~g}, \mathrm{Lm}=3,1 \mathrm{~cm}$.
\end{abstract}

\section{Kata kunci : Daphnia sp., Larva Tawes, Vitamin D.}

\section{PENDAHULUAN}

Budidaya perikanan merupakan salah satu sumber penghasilan yang cukup besar dan menjanjikan. Pemerintah Indonesia telah melaksanakan pembangunan di bidang sektor perikanan, yaitu dengan pengembangan budidaya ikan air tawar, air payau, dan laut. Kondisi perikanan di Indonesia mengalami penurunan dari tahun ke tahun. Ikan Tawes adalah ikan yang telah lama dibudidayakan karena cocok di Indonesia yang beiklim tropis. Sehingga ikan ini dapat dibudidayakan sepanjang tahun (Cahyono, 2011). Sebagai ikan konsumsi ikan Tawes mempunyai juga kelemahan yaitu mempunyai duri yang banyak pada dagingnya. Ikan Tawes dapat berkembang biak pada usia yang relatif mudah dengan frekuensi pemijahan sebulan sekali. Dengan kelebihan tersebut, budididaya ikan tawes diharapkan dapat memberikan penghasilan tambahan bagi petani (Susanto, 2000).

Pakan alami memiliki karakteristik yang unik karena dapat bergerak aktif sehingga mengundang daya tarik ikan untuk memakannya. Jenis pakan alami yang dimakan ikan sangat beragam, tergantung pada jenis ikan dan tingkat umurnya. Contohnya Daphnia sp. keunggulan 
pakan alami terhadap ikan yakni memiliki daya tarik terhadap ikan, tidak mempengaruhi kualitas air, mengandung banyak serat sehingga pencernaan ikan tetap baik, dan memiliki kandungan nutrisi yang sesuai dengan nutrisi yang dibutuhkan ikan (Prastya, et. al, 2016).

Pemberian vitamin sangat dianjurkan dalam proses pembenihan ikan Tawes, dikarenakan pada proses ini ikan sangat rentan terhadap kematian. Salah satu upaya yang dilakukan adalah dengan penambahan vitamin D. Vitamin D adalah salah satu jenis vitamin yang larut dalam lemak prohormon yang juga dikenal dengan nama kalsiferol. Vitamin D sendiri memiliki 2 bentuk aktif yaitu vitamin D2 dan D3. Vitamin D2 atau dikenal juga dengan nama ergokalsiferol ini bersal dari turunan senyawa kolesterol yang banyak ditemukan pada ragi dan tanaman. Vitamin D3 (kolekalsiferol) sendiri berasal dari turunan senyawa 7dehidrokolesterol. Fungsi utama vitamin D adalah membantu pembentukan dan pemeliharaan tulang dan fungsi khusus vitamin $\mathrm{D}$ dalam hal ini adalah membantu pengerasan tulang dengan cara mengatur agar kalsium dan fosfor tersedia di dalam darah untuk diendapkan pada proses pengerasan tulang (Imanuel, 2015).

Penelitian yang dilakukan oleh Ningsih (2016), menunjukkan bahwa pemberian vitamin D dengan dosis 80 ppm memberikan hasil yang baik terhadap peningkatan kualitas pertumbuhan ikan Patin (Pangasius hypophthalmus) serta penelitian Karyati (2017), menunjukan bahwa pemberian vitamin D pada larva ikan Gurame dengan dosis $25 \mathrm{mg} / \mathrm{l}$ menunjukan hasil yang baik terhadap peningkatan kualitas pertumbuhan larva ikan.

Berdasarkan uraian diatas menjadi dasar melatar belakangi untuk mengetahui analisis kinerja pertumbuhan benih ikan Tawes yang diberi pakan Dapnia sp. yang dikombinasi dengan vitamin D dengan media aquarium, dikarenakan memudahkan pada saat pengontrolan benih ikan Tawes dan peneliti ingin mengetahui seberapa besarkah pengaruh vitamin $\mathrm{D}$ pada larva ikan Tawes dengan dosis $0 \mathrm{mg} / \mathrm{l}, 25 \mathrm{mg} / \mathrm{l}, 50 \mathrm{mg} / \mathrm{l}, 75 \mathrm{mg} / \mathrm{l}$ dan $100 \mathrm{mg} / \mathrm{l}$. Berdasarkan hal tersebut penulis melakukan penelitian analisis kinerja pertumbuhan larva ikan Tawes yang diberi pakan Daphnia sp. yang dikombinasi dengan vitamin D.

\section{Metode Penelitian}

\section{A. Waktu dan Tempat}

Kegiatan penelitian dilaksanakan selama dua bulan pada bulan Mei sampai dengan Juni 2017. Penelitian dilakukan di Balai Benih Ikan Ciganjur (PPISHP), Jalan Mohammad Kahfi 1 No.1 Jagakarsa, RT.7/RW.3 Jakarta Selatan, Kota Jakarta Selatan Daerah Khusus Ibukota 
Jakarta 12630. Pengukuran analisis proksimat dan analisis kimia di Laboratorium Sekolah Tinggi Perikanan (STP).

\section{B. Bahan dan Alat}

\section{- Bahan}

Penelitian ini dilakukan dengan menggunakam bahan sebagai berikut : Larva Ikan Tawes 3 - 4 hari ukuran 0,5 cm degan jumlah 1500 ekor sebagai bahan uji penelitian. Kepadatan ikan uji adalah 100 ekor/akuarium, Daphnia sp. sebagai pakan alami ikan Tawes dan vitamin D (satu) Botol merek Ostelin.

\section{- Alat}

Alat yang digunakan pada penelitian dalam pemeliharaan ikan Tawes antara lain sebagai berikut : Peralatan aerasi untuk suplai oksigen kedalam air, selang sipon digunakan untuk membuang kotoran didasar wadah, gelas ukur 1 buah yang digunakan untuk wadah pengukur Daphnia sp., ember untuk pemindahan ikan, selang air sepanjang $15 \mathrm{~m}$ untuk mensuplai air ke wadah, serokan ikan untuk menangkap ikan, baskom untuk perendaman Daphnia sp. dalam larutan, timbangan digital untuk menimbang benih ikan, penggaris untuk mengukur panjang benih dan alat tulis sebagai menulis data penelitian, kamera untuk dokumentasi, alat cek kualitas air.

\section{Rancangan Percobaan}

Metode yang digunakan dalam penelitian ini adalah metode eksperimen yaitu serangkaian percobaan untuk melihat sesuatu hasil dan menggunakan Rancangan Acak Lengkap (RAL). Penelitian ini menggunakan lima perlakuan dan tiga kali ulangan. Perlakuan yang diterapkan berupa tingkatan dosis vitamin D yang berbeda. Parameter dianalisis menggunakan sidik ragam (ANOVA) jika terdapat perbedaan maka dilanjutkan dengan uji jarak berganda Duncan.

- Perlakuan I Kontrol : Tanpa diberi kombinasi penambahan vitamin D pada Daphnia sp.

- Perlakuan II Dosis 25 mg/l : Diberi vitamin D sebanyak 25 mg/l pada Daphnia sp.

- Perlakuan III Dosis 50 mg/l: Diberi vitamin D sebanyak 50 mg/l pada Daphnia sp

- Perlakuan IV Dosis 75 mg/l : Diberi vitamin D sebanyak 75 mg/l pada Daphnia sp.

- Perlakuan V Dosis 100 mg/l: Diberi vitamin D sebanyak 100 mg/l pada Daphnia sp. 


\section{Hasil dan Pembahasan}

\section{A. Pertumbuhan Bobot (g)}

Hasil pengamatan terhadap pertumbuhan bobot pada semua larva ikan Tawes selama penelitian menunjukan hasil yang baik terhadap peningkatan pertumbuhan. Hasil ini dapat dilihat pada Tabel 1 di bawah ini. Nilai rata-rata pertumbuhan bobot larva Tawes yang tertinggi terdapat pada pemberian dosis $25 \mathrm{mg} / \mathrm{l}$ diberikan dosis vitamin $\mathrm{D}$ berdasarkan hasil penelitian yang dilakukan dalam wadah percobaan yaitu perlakuan $0 \mathrm{mg} / \mathrm{l}, 25 \mathrm{mg} / \mathrm{l}, \quad 50 \mathrm{mg} / \mathrm{l}, \quad 75 \mathrm{mg} / \mathrm{l}$, 100 mg/l, selengkapnya dapat dilihat pada Tabel 1.

Tabel 1. Hasil Pertambahan Bobot (g) Larva Ikan Tawes.

\begin{tabular}{|c|c|c|c|c|c|}
\hline \multirow[b]{2}{*}{ Ulangan } & \multicolumn{5}{|c|}{$\begin{array}{l}\text { Perlakua } \\
\text { n }\end{array}$} \\
\hline & $\begin{array}{c}\text { Dap; } \\
\text { Vit. } \\
\text { D } \\
\text { Dosis } \\
\text { 0 } \\
\text { mg/l }\end{array}$ & $\begin{array}{l}\text { Dap;Vit } \\
\text { D } \\
\text { Dosis25 } \\
\text { mg/l }\end{array}$ & $\begin{array}{l}\text { Dap;Vit } \\
\text { D } \\
\text { Dosis50 } \\
\text { mg/l }\end{array}$ & $\begin{array}{l}\text { Dap;Vit. } \\
\text { D } \\
\text { Dosis75 } \\
\text { mg/l }\end{array}$ & $\begin{array}{l}\text { Dap;V } \\
\text { it.D } \\
\text { Dosis } \\
\text { 100 } \\
\text { mg/l }\end{array}$ \\
\hline 1 & 37,6 & 237,1 & 72,4 & 45,4 & 10,2 \\
\hline 2 & 57,8 & 233,5 & 75,2 & 28,4 & 14,6 \\
\hline 3 & 62,5 & 266,8 & 58 & 36,4 & 20,2 \\
\hline $\begin{array}{c}\text { Rata-rat } \\
\text { a }\end{array}$ & 52,6 & 245,1 & 68,5 & 36,7 & 15,0 \\
\hline
\end{tabular}

Keterangan :

- Dap = Daphnia sp.

- Vit.D = Vitamin D

Nilai pertambahan bobot larva ikan Tawes pada Tabel 3 di atas menunjukkan bahwa pertambahan yang terbaik ditemukan pada pemberian dosis Daphnia sp. yang dikombinasi vitamin D, hasil ini sesuai dengan penelitian sebelumnya yang menjukan bahwa pemberian 
vitamin D pada larva menunjukan hasil peningkatan yang signifikan pada ikan Patin (Ningsih, 2016). Dari hasil penelitian diatas menunjukan bahwa vitamin D dapat meningkatkan pertambahan pada tulang.

Data pertambahan bobot pada Tabel 1 diolah dengan menggunakan SPSS. Adapun hasil tersebut dapat dilihat pada Tabel 2.

Tabel 2. Hasil Uji Lanjut Pertambahan Bobot (g) Larva Tawes Selama

\begin{tabular}{|l|l|l|l|}
\hline Perlakuan dosis & Wm $(\mathrm{g})$ & F hit & Sig (a) \\
\hline $0 \mathrm{mg} / \mathrm{l}$ & $52,6 \pm 13,2 \mathrm{bc}$ & & \\
\cline { 1 - 2 } $25 \mathrm{mg} / \mathrm{l}$ & $245,1 \pm 18,7 \mathrm{~d}$ & & \\
\cline { 1 - 2 } $50 \mathrm{mg} / \mathrm{l}$ & $68,5 \pm 7,2 \mathrm{c}$ & & \\
\cline { 1 - 2 } $75 \mathrm{mg} / \mathrm{l}$ & $36,7 \pm 8,5 \mathrm{~b}$ & & \\
\hline $100 \mathrm{mg} / \mathrm{l}$ & $15,0 \pm 8,6 \mathrm{a}$ & \\
\hline
\end{tabular}

Keterangan: Huruf superscript yang berbeda menunjukkan hasil yang

Hasil analisis uji lanjut pada Tabel 4, menyatakan bahwa perbedaan pemberian dosis vitamin D pada Daphnia sp. menunjukan nilai yang signifikan antar perlakuan. Pemberian pakan Daphnia sp. yang dikombinasi dengan vitamin D dengan dosis $25 \mathrm{mg} / \mathrm{l}$ memberikan pengaruh yang nyata terhadap perlakuan semua dosis, dengan nilai $245,1 \mathrm{~g}$. dari hasil dosis $0 \mathrm{mg} / \mathrm{l}$ tidak berbeda nyata dari dosis $50 \mathrm{mg} / 1$ dan dosis $75 \mathrm{mg} / \mathrm{l}$, pada dosis $50 \mathrm{mg} / \mathrm{l}$ berbeda nyata terhadap perlakuan dosis $75 \mathrm{mg} / \mathrm{l}, 25 \mathrm{mg} / \mathrm{l}$ dan $100 \mathrm{mg} / \mathrm{l}$, perlakuan dosis $100 \mathrm{mg} / \mathrm{l}$ berbeda nyata dari semua perlakuan dosis. Hasil analisis tersebut sesuai dengan peneliti sebelumnya bahwa penambahan vitamin D pada pakan dapat menunjukan nilai yang signifikan terhadap kontrol.

Hasil uji lanjut menunjukan bahwa sig adalah .000<0,05 maka Ho ditolak dan H1 diterima, artinya kombinasi vitamin D pada Daphnia sp. dengan dosis yang berbeda-beda ada pengaruh terhadap pertambahan bobot larva ikan Tawes. Hal ini diperkirakan terjadi karena larva ikan Tawes membutuhkan asupan vitamin D dari luar.

Hasil pertambahan bobot (g) ikan Tawes selengkapnya dapat dilihat pada Gambar 1. 


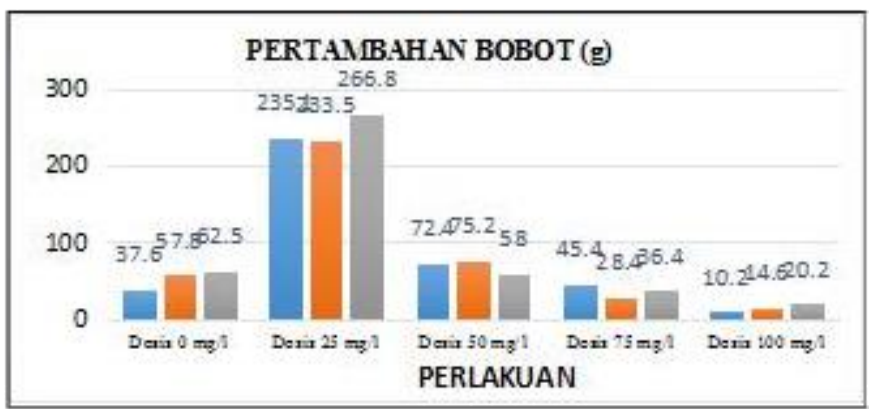

Gambar 1. Hasil Pertambahan Bobot (g) Larva Ikan Tawes

Berdasarkan Gambar di atas dapat disimpulkan bahwa pertumbuhan Rata-rata

tertinggi bobot larva ikan Tawes yang diberikan dosis vitamin D terdapat pada perlakuan 25 $\mathrm{mg} / \mathrm{l}$ dengan berat 245,1 gram dan diikuti perlakuan $50 \mathrm{mg} / \mathrm{l}$ dengan berat 68,5 gram, perlakuan $0 \mathrm{mg} / \mathrm{l}$ dengan berat 52,6 gram dan perlakuan $75 \mathrm{mg} / \mathrm{l}$ dengan berat 36,7 gram, perlakuan terendah pada perlakuan $100 \mathrm{mg} / \mathrm{l}$ dengan berat 15,0 gram.

\section{B. Pertumbuhan Panjang (cm)}

Rata-rata jumlah pertumbuhan panjang larva ikan Tawes yang diberikan dosis vitamin D berdasarkan hasil penelitian yang dilakukan dalam wadah percobaan yaitu perlakuan $0 \mathrm{mg} / \mathrm{l}, 25$ $\mathrm{mg} / \mathrm{l}, 50 \mathrm{mg} / \mathrm{l}, 75 \mathrm{mg} / \mathrm{l}, 100 \mathrm{mg} / \mathrm{l}$. Pengukuran dihitung menggunakan penggaris dengan tingkat ketelitian $0,1 \mathrm{~cm}$, lalu di rata-ratakan dari masing-masing perlakuan hasil perhitungan dapat dilihat pada Tabel 3 .

Tabel 3. Hasil Pertumbuhan Panjang (cm) Larva Ikan Tawes.

\begin{tabular}{|c|c|c|c|c|c|}
\hline ulangan & Perlakuan & & & & \\
\hline & $\begin{array}{ll}\text { Dap;vit } & \text { D } \\
\text { dosis } & 0 \\
\text { mg/l } & \end{array}$ & $\begin{array}{ll}\text { Dap;vit } & \text { D } \\
\text { dosis } & 25 \\
\mathrm{mg} / \mathrm{l} & \end{array}$ & $\begin{array}{ll}\text { Dap;vit } & \text { D } \\
\text { dosis } & 50 \\
\mathrm{mg} / \mathrm{l} & \end{array}$ & $\begin{array}{ll}\text { Dap;vit } & \text { D } \\
\text { dosis } & 75 \\
\text { mg/l } & \end{array}$ & $\begin{array}{lr}\text { Dap;vit } & \text { D } \\
\text { dosis } & 100 \\
\mathrm{mg} / \mathrm{l} & \end{array}$ \\
\hline 1 & 0,9 & 2,9 & 1,5 & 1,4 & 1,2 \\
\hline 2 & 1,3 & 3,1 & 1,2 & 1,2 & 1 \\
\hline 3 & 1,4 & 3,2 & 1,3 & 1,1 & 1,2 \\
\hline Rata-rata & 1,2 & 3,1 & 1,3 & 1,2 & 1,1 \\
\hline
\end{tabular}

Keterangan :

- Dap = Daphnia sp.

- Vit.D = Vitamin D 
Pada Tabel 3 terlihat bahwa pertumbuhan panjang rata-rata larva ikan Tawes yang paling

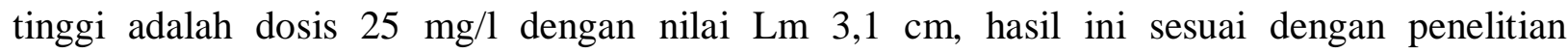
sebelumnya yang menunjukan pemberian vitamin D pada pakan alami dengan dosis yang tepat akan mempengaruhi hasil pertumbuhan panjang yang baik (Ningsih, 2016). Pertumbuhan panjang larva ikan Tawes ini terdapat 4 data yang berbeda nyata hasil Lm yang sama yaitu pada dosis $0 \mathrm{mg} / \mathrm{l}, 50 \mathrm{mg} / \mathrm{l}, 75 \mathrm{mg} / \mathrm{l}$ dan $100 \mathrm{mg} / \mathrm{l}$. Menunjukkan nilai Lm dosis $0 \mathrm{mg} / \mathrm{l}$ dan $50 \mathrm{mg} / \mathrm{l}$, 1,2 dan dosis $75 \mathrm{mg} / \mathrm{l}$ dan $100 \mathrm{mg} / \mathrm{l}$, menunjukkan nilai $\mathrm{Lm} \mathrm{1,2}$ dan $1,1 \mathrm{~cm}$. Hal ini menunjukkan Bahwa parameter pertumbuhan panjang, larva ikan Tawes tumbuh optimal pada pertumbuhan dosis $25 \mathrm{mg} / \mathrm{l}$ dan pada dosis $0 \mathrm{mg} / \mathrm{l}, 50 \mathrm{mg} / \mathrm{l}, 75 \mathrm{mg} / \mathrm{l}$, dan $100 \mathrm{mg} / \mathrm{l}$ masih bisa tumbuh walaupun pertumbuhan panjang rendah dan sama. Jika dibandingkan dengan dosis 0 mg/l, 25 mg/l (1,9), 0 mg/l dengan 50 mg/l (0,1), 0 mg/l dengan 75 mg/l (0), dan kalau pada dosis $0 \mathrm{mg} / \mathrm{l}$ dengan $100 \mathrm{mg} / \mathrm{l}(-0,1)$, peningkatan yang tinggi pada dosis $25 \mathrm{mg} / \mathrm{l}$ dengan peningkatan 1,9 artinya sebagai pakan alami memberikan hasil pertumbuhan panjang dan pertumbuhan larva ikan Tawes paling baik.

Hasil uji lanjut menunjukan bahwa sig adalah .000<0,05 maka Ho ditolak dan H1 diterima, artinya kombinasi vitamin D pada Daphnia sp. dengan dosis yang berbeda-beda ada pengaruh terhadap pertumbuhan panjang larva ikan Tawes. Hal ini diperkirakan terjadi karena larva ikan Tawes membutuhkan asupan vitamin D dari luar.

Tabel 4. Hasil Uji Lanjut Pertumbuhan Panjang (cm) Larva Ikan Tawes Selama Penelitian.

\begin{tabular}{|c|l|c|c|}
\hline Perlakuan Dosis & \multicolumn{1}{|c|}{ Lm (cm) } & F hitung & Sig (a) \\
\hline $0 \mathrm{mg} / \mathrm{l}$ & $1,2 \pm 0,2 \mathrm{a}$ & & \\
\hline $25 \mathrm{mg} / \mathrm{l}$ & $3,1 \pm 0,1 \mathrm{~b}$ & 66,8 & .000 \\
\hline $50 \mathrm{mg} / \mathrm{l}$ & $1,3 \pm 0,3 \mathrm{a}$ & \\
\hline $75 \mathrm{mg} / \mathrm{l}$ & $1,3 \pm 0,1 \mathrm{a}$ & & \\
\hline $100 \mathrm{mg} / \mathrm{l}$ & $1,1 \pm 0,1 \mathrm{a}$ & & \\
\hline
\end{tabular}

Keterangan: Huruf superscript yang berbeda menunjukkan hasil yang berbeda nyata $(\mathrm{p}<0,05)$

Hasil uji lanjut pada Tabel 4 menunjukan bahwa pemberian dosis vitamin D pada Daphnia sp. menunjukan yang berbeda nyata. Pemberian pakan Daphnia sp. yang dikombinasi dengan 
vitamin D pada perlakuan dosis $25 \mathrm{mg} / \mathrm{l}$ dengan jumlah $3,1 \mathrm{~cm}$ adalah dosis yang terbaik, dikarenakan penggunaan dosis yang tepat akan mempermudah proses pembentukan struktur tulang, berbanding terbalik dengan pemberian dosis yeng tidak tepat akan mengakibatkan kerusakan pada struktur tulang (Imanuel, 2015). Menunjukan hasil yang berbeda nyata terhadap perlakuan lainnya. pada dosis $0 \mathrm{mg} / \mathrm{l}, 50 \mathrm{mg} / \mathrm{l}, 75 \mathrm{mg} / \mathrm{l} \mathrm{dan} 100 \mathrm{mg} / \mathrm{l}$ menunjukan hasil yang tidak berbeda nyata,

Hasil peningkatan panjang ikan Tawes selengkapnya dapat dilihat pada Gambar 2.

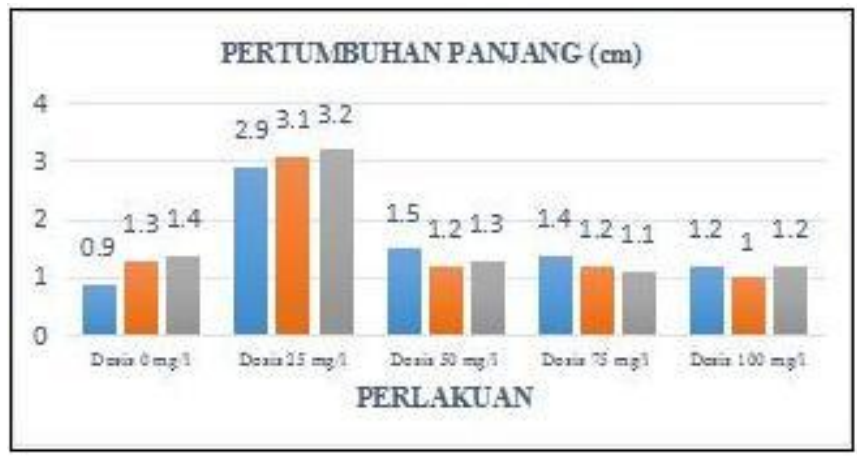

Gambar 2. Hasil Pertumbuhan Panjang (cm) Larva Ikan Tawes.

Berdasarkan Gambar 2 di atas dapat disimpulkan bahwa pertumbuhan panjang larva ikan Tawes perlakuan tertinggi pada perlakuan $25 \mathrm{mg} / 1$ dengan panjang 3,1 $\mathrm{cm}$ dan diikuti perlakuan $50 \mathrm{mg} / \mathrm{l}$ dengan panjang $1.3 \mathrm{~cm}$, perlakuan $0 \mathrm{mg} / \mathrm{l}$ dengan panjang 1,2 cm dan perlakuan $75 \mathrm{mg} / \mathrm{l}$ dengan panjang 1,2 cm, perlakuan terendah pada perlakuan $100 \mathrm{mg} / 1$ dengan panjang $1,1 \mathrm{~cm}$. rendah, sementara pada kegiatan pembenihan ikan Tawes yang di utamakan selain SR adalah panjang ikan tetapi selama kegiatan pembenihan tubuh ikan normal tidak ada yang cacat meskipun pertambahan panjang lambat. Oleh karena itu pada proses pembenihan perlu diperhatikan untuk pemberian vitamin D pada larva ikan Tawes. Sedangkan vitamin D dengan dosis tinggi akan meningkatkan resorpsi tulang dan toxic sehingga penambahan vitamin D dengan dosis berlebih akan mengganggu pertumbuhan tulang (Imanuel et al, 2015). Penelitian sebelumnya menyatakan bahwa kelebihan dosis pada larva ikan gurame menyebabkan tingkat kelangsungan hidup menurun, sehingga dosis yang digunakan harus tepat (Karyati, 2017). Penelitian ini juga didukung oleh Herawati et al, 2012) menyatakan bahwa pakan alami sebagai pakan awal sangat mendukung kualitas yang baik dari larva ikan. Salah satu contoh pakan alami untuk larva ikan gurame adalah kutu air (Daphnia sp).

\section{Kelangsungan Hidup (SR)}


Rata-rata jumlah kelangsungan hidup larva ikan Tawes yang diberikan dosis vitamin D berdasarkan hasil penelitian yang dilakukan dalam wadah percobaan yaitu perlakuan $0 \mathrm{mg} / \mathrm{l}, 25$ $\mathrm{mg} / 150 \mathrm{mg} / \mathrm{l}, 75 \mathrm{mg} / \mathrm{l}, 100 \mathrm{mg} / \mathrm{l}$, selengkapnya dapat dilihat pada Tabel 5.

Tabel 5. Hasil Kelangsungan Hidup (\%) Larva Ikan Tawes

\begin{tabular}{|c|c|c|c|c|c|}
\hline ulangan & Perlakuan & & & & \\
\hline & $\begin{array}{ll}\text { Dap;vit } & \text { D } \\
\text { dosis } & 0 \\
\mathrm{mg} / \mathrm{l} & \end{array}$ & $\begin{array}{ll}\text { Dap;vit } & \text { D } \\
\text { dosis } & 25 \\
\text { mg/l } & \end{array}$ & $\begin{array}{lr}\text { Dap;vit } & \text { D } \\
\text { dosis } & 50 \\
\mathrm{mg} / 1 & \end{array}$ & $\begin{array}{ll}\text { Dap;vit } & \text { D } \\
\text { dosis } & 75 \\
\text { mg/l } & \end{array}$ & $\begin{array}{lr}\text { Dap;vit } & \text { D } \\
\text { dosis } & 100 \\
\mathrm{mg} / \mathrm{l} & \end{array}$ \\
\hline 1 & 73 & 87 & 72 & 53 & 43 \\
\hline 2 & 77 & 81 & 64 & 49 & 38 \\
\hline 3 & 75 & 88 & 60 & 48 & 39 \\
\hline Rata-rata & 75 & 85 & 65 & 50 & 40 \\
\hline
\end{tabular}

Keterangan :

- Dap = Daphnia sp.

- Vit.D = Vitamin D

Pada Tabel 5 menunjukkan kelangsungan hidup akhir yang paling tinggi adalah dosis $25 \mathrm{mg} / \mathrm{l}$ sebanyak $85 \%$ dikarenakan pemberian dosis vitamin D yang tepat akan mempengaruhi kelangsungan hidup pada larva ikan, berbanding terbalik jika pemberian dosis yang tidak tepat akan mengakibatkan tingkat kelangsungan hidup pada larva ikan akan menurun (Ningsih, 2016). Kelangsungan hidup yang paling rendah adalah dosis $100 \mathrm{mg} / \mathrm{l}$ sebanyak $40 \%$. Hal ini menunjukkan bahwa kombinasi vitamin D pada Daphnia sp. sebagai pakan larva ikan Tawes memberikan pengaruh yang signifikan dan terdapat data yang berbeda nyata dosis $50 \mathrm{mg} / 1,75$ $\mathrm{mg} / \mathrm{l}$ dan $100 \mathrm{mg} / \mathrm{l}$.

Tabel 6. Hasil Uji Lanjut Tingkat Kelangsungan Hidup (\%) Larva Ikan Tawes Selama Penelitian.

\begin{tabular}{|c|c|c|c|}
\hline Perlakuan Dosis & SR $(\%)$ & F hitung & Sig (a) \\
\hline $0 \mathrm{mg} / \mathrm{l}$ & $75 \pm 2,1 \mathrm{~d}$ & \multirow{2}{*}{72,4} & .000 \\
\hline $25 \mathrm{mg} / \mathrm{l}$ & $85 \pm 3,8 \mathrm{e}$ & & \\
\hline $50 \mathrm{mg} / \mathrm{l}$ & $65 \pm 6,2 \mathrm{c}$ & & \\
\hline
\end{tabular}




\begin{tabular}{|c|l|l|l|}
\hline $75 \mathrm{mg} / \mathrm{l}$ & $50 \pm 2,6 \mathrm{~b}$ & & \\
\cline { 1 - 2 } $100 \mathrm{mg} / \mathrm{l}$ & $40 \pm 2,6 \mathrm{a}$ & & \\
\hline
\end{tabular}

Hasil uji lanjut pada Tabel 6 menunjukan bahwa pemberian dosis vitamin D pada Daphnia sp. menunjukan hasil yang berbeda nyata. Pemberian pakan Daphnia sp. yang dikombinasi dengan vitamin D pada perlakuan dosis $25 \mathrm{mg} / \mathrm{l}$ dengan jumlah $85 \%$ menunjukan hasil yang signifikan dan berbeda nyata terhadap semua perlakuan. Pada dosis $0 \mathrm{mg} / \mathrm{l}, 50 \mathrm{mg} / \mathrm{l}$, $75 \mathrm{mg} / \mathrm{l}, 100 \mathrm{mg} / \mathrm{l}$ menunjukan hasil yang berbeda nyata.

Hasil uji lanjut menunjukan bahwa sig adalah .000<0,05 maka Ho ditolak dan H1 diterima, artinya kombinasi vitamin D pada Daphnia sp. dengan dosis yang berbeda-beda ada pengaruh terhadap pertumbuhan panjang larva ikan Tawes. Hal ini diperkirakan terjadi karena larva ikan Tawes membutuhkan asupan vitamin D dari luar.

Agar mempermudah membandingkan hasil SR yang di dapat dari Tabel 6, yaitu perbedaan SR dan larva ikan Tawes dengan penambahan dosis yang berbeda-beda dapat dilihat dari Gambar 3.

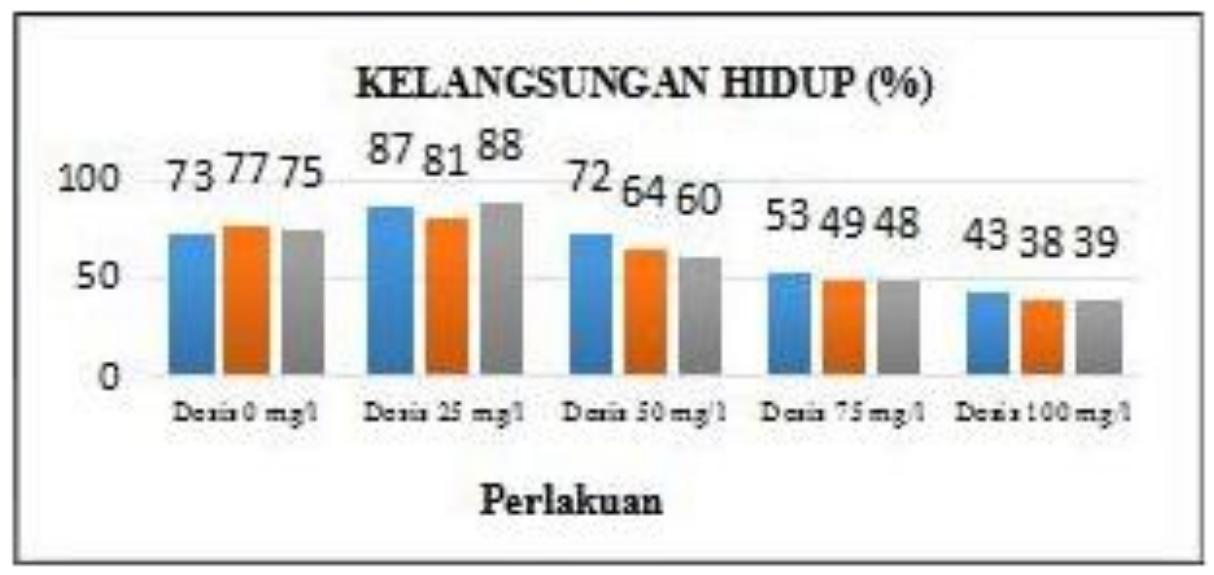

Gambar 3. Hasil Kelangsungan Hidup (\%) Larva Ikan Tawes.

Berdasarkan Gambar 3 di atas dapat disimpulkan bahwa rata-rata kelangsungan hidup larva ikan Tawes perlakuan tertinggi pada perlakuan $25 \mathrm{mg} / \mathrm{l}$ dengan nilai $85 \%$ dan di ikuti perlakuan $0 \mathrm{mg} / \mathrm{l}$ dengan nilai $75 \%$, perlakuan $50 \mathrm{mg} / \mathrm{l}$ dengan nilai $65 \%$ dan perlakuan $75 \mathrm{mg} / \mathrm{l}$ dengan nilai $50 \%$, perlakuan terendah pada perlakuan $100 \mathrm{mg} / \mathrm{l}$ dengan nilai $45 \%$. Hal ini didukung oleh (Ningsih, 2016) dan (Karyati, 2017) bahwa pemberian vitamin D pada larva ikan 
menunjukan hasil yang signifikan, yaitu penggunaan dosis $80 \mathrm{mg} / \mathrm{l}$ pada larva ikan Patin (Pangasionodon hypopthalmus) dan $25 \mathrm{mg} / \mathrm{l}$ pada larva ikan Gurame (Osphronemus gouramy). Menurut Subandiyono dan Hastuti, (2010). Menambahkan bahwa pertumbuhan akan terjadi apabila didukung dengan pemberian pakan yang disesuaikan dengan kebutuhan nutrisi ikan.

\section{Hasil Uji Laboratorium Komposisi Proksimat Daphnia sp. Yang Sudah Terkandung Vitamin D}

Hasil pengamatan dari uji labolaturium yang dilakukan Sekolah Tinggi Perikanan (STP) dapat di lihat pada Tabel 7.

Tabel 7. Hasil Komposisi Uji Proksimat (\%) Daphnia sp

\begin{tabular}{|c|c|c|c|c|}
\hline $\begin{array}{c}\text { Kode } \\
\text { sampel }\end{array}$ & Protein & Lemak & Air & Abu \\
\hline DDVD 0mg/l & 10.69 & 0,45 & 81,78 & 3,88 \\
\hline $\begin{array}{c}\text { DDVD } \\
25 \mathrm{mg} / 1\end{array}$ & 12,88 & 0,78 & 82,63 & 4,19 \\
\hline $\begin{array}{c}\text { DDVD } \\
50 \mathrm{mg} / 1\end{array}$ & 10,69 & 0,43 & 81,64 & 3,79 \\
\hline $\begin{array}{c}\text { DDVD } \\
75 \mathrm{mg} / 1\end{array}$ & 10,31 & 0,37 & 81,23 & 3,09 \\
\hline $\begin{array}{c}\text { DDVD } \\
100 \mathrm{mg} / 1\end{array}$ & 10,23 & 0,35 & 78,15 & 2,57 \\
\hline
\end{tabular}

Keterangan :

- DDVD : Daphnia Dosis Vitamin D

Pada Tabel 7 dapat dilihat kadar protein 12,88 \%, lemak 0,78\%, air 82,63\%, dan abu 4,19\% tertinggi pada dosis $25 \mathrm{mg} / \mathrm{l}$, sedangkan pada dosis terendah $100 \mathrm{mg} / \mathrm{l}$ dengan kadar protein $10,23 \%$, lemak $0,35 \%$, air $78,15 \%$, dan abu 2,57 \%. Hal ini menyatakan bahwa pemberian dosis vitamin D yang tepat dapat terserap oleh Daphnia sp. sehingga kandungan nutrisi dalam Daphnia sp. meningkat, berbanding terbalik jika pemberian dosis vitamin D tidak 
sesuai akan mengakibatkan toksisitas pada Daphnia sp. Dan kandungan nutrisi menurun penelitian ini didukung oleh (Ningsih, 2016).

\section{E. Hasil Uji Laboratorium Komposisi Proksimat Pada Larva Ikan Tawes}

Hasil pengamatan dari uji labolaturium yang dilakukan Sekolah Tinggi Perikanan (STP) dapat di lihat pada Tabel 8.

Tabel 8. Hasil Komposisi Proksimat (\%) Larva Ikan Tawes.

\begin{tabular}{|c|c|c|c|c|c|}
\hline No & Kode sampel & Protein & Lemak & Air & Abu \\
\hline 1 & TDVD 0mg/l & 15,52 & 0,42 & 81,46 & 3,48 \\
\hline 2 & TDVD 25mg/l & 15,89 & 0,75 & 84,63 & 4,59 \\
\hline 3 & TDVD 50mg/l & 14,80 & 0,38 & 81,44 & 2,99 \\
\hline 4 & TDVD 75mg/l & 14,31 & 0,24 & 78,23 & 2,79 \\
\hline 5 & TDVD 100mg/l & 14,55 & 0,27 & 76,15 & 2,67 \\
\hline
\end{tabular}

Keterangan :

- TDVD : Tawes Dosis Vitamin D

Pada Tabel 8 dapat dilihat kadar protein 15,89\%, lemak 0,75\%, air 84,63\%, dan abu 4,59\% tertinggi pada dosis $25 \mathrm{mg} / \mathrm{l}$, sedangkan pada dosis terandah $100 \mathrm{mg} / \mathrm{l}$ dengan kadar protein $14,55 \%$, lemak $14,55 \%$, air $76,15 \%$, dan abu 2,67 \%. Hal ini terjadi karena protein yang seharusnya dioptimalkan untuk pertumbuhan dialihkan sebagai pengatur metabolisme tubuh akibat vitamin D yang dikonsumsi terlalu tinggi pada larva menjadikan metabolisme tubuh pada larva ikan Tawes tidak stabil dan juga pemberian vitamin D dengan dosis yang tepat mempengaruhi kandungan lemak yang terdapat pada larva ikan Tawes tersebut karena peran lemak yang seharusnya sebagai salah satu sumber energi dialihkan untuk membantu proses pelarutan vitamin dalam tubuh larva ikan Tawes. Penelitian Ningsih, (2016) menyatakan bahwa pemberian dosis vitamin D pada Daphnia sp. yang tepat dapat mempengaruhi kadar nutrisi pada daging ikan, berbanding terbalik jika pemberian dosis vitamin D tidak sesuai akan mengakibatkan penurunan kualitas nutrisi pada daging ikan. 


\section{F. Kualitas Air}

Dalam pemeliharaan larva ikan Tawes kualitas air paling penting karena sangat berpengaruh pada tingkat kelangsungan hidup dan larva ikan Tawes.

Tabel 9. Hasil Pengukuran kualitas air selama penelitian.

\begin{tabular}{|c|c|c|c|c|c|c|}
\hline & \multicolumn{5}{|c|}{ Akuarium } & $\begin{array}{c}\text { Referen } \\
\text { sipp } \\
\text { Parameter }\end{array}$ \\
\cline { 2 - 6 } & $\begin{array}{c}\text { Dosis } \\
\mathbf{0} \\
\text { ppm }\end{array}$ & $\begin{array}{c}\text { Dosis } \\
\mathbf{2 5} \\
\mathbf{p p m}\end{array}$ & $\begin{array}{c}\text { Dosis } \\
\mathbf{5 0} \\
\mathbf{p p m}\end{array}$ & $\begin{array}{c}\text { Dosis } \\
\mathbf{7 5} \\
\mathbf{p p m}\end{array}$ & $\begin{array}{c}\text { Dosis } \\
\mathbf{1 0 0} \\
\mathbf{p p m}\end{array}$ & $\begin{array}{c}\text { tahun } \\
\mathbf{2 0 0 1}\end{array}$ \\
\hline $\begin{array}{c}\text { Suhu } \\
\text { (c) }\end{array}$ & $28-30$ & $28-30$ & $28-30$ & $28-30$ & $28-30$ & $28-32$ \\
\hline pH & $6-7$ & 7 & $6-7$ & $6-7$ & $6-7$ & $6,8-8,5$ \\
\hline $\begin{array}{c}\text { DO } \\
(\mathrm{ppm})\end{array}$ & $5,8-6$ & $5,9-6$ & $5,5-6$ & $5-5,5$ & $5-5,5$ & $\geq 5$ \\
\hline $\begin{array}{c}\text { Amoniak } \\
(\mathrm{ppm})\end{array}$ & $1-1,5$ & $1-1,5$ & $1,5-2$ & $2-2,5$ & $2-2,5$ & $\leq 1$ \\
\hline
\end{tabular}

Dari hasil pengukuran kualitas air pada akhir penelitian dilakukan 28 hari selama pemeliharaan larva. Pengukuran dilakukan setiap perlakuan dan pengulangan dari data pengulangan masing-masing perlakuan dirata-ratakan sehingga mendapatkan hasil seperti pada Tabel 9.

Hasil penelitian ini didukung dengan Boyd (1982) dalam Nirmala dan Rasmawan (2010), menyatakan bahwa nilai pH yang mematikan bagi ikan, yaitu kurang dari 4 dan lebih dari 11 . Pada pH kurang dari 6,5 atau lebih dari 9,5 dalam waktu yang lama,akan mempengaruhi pertumbuhan dan reproduksi ikan.Jika nilai $\mathrm{pH}$ air rendah dapat menyebabkan terjadinya penggumpalan lendir pada insang dan ikan akan mati lemas sehingga makanan yang dikonsumsi lebih banyak dimanfaatkan sebagai energi untuk mempertahankan tubuh dari pada untuk pertumbuhan menurut Zonneveld et al, (1991). Aquarista, (2012) menambahkan bahwa secara teknis upaya untuk memperbaiki kualitas air dilakukan dengan cara penyiponan atau pergantian air secara berkala.

Oksigen terlarut (DO) merupakan parameter kualitas air yang sangat penting karena keberadaannya mutlak diperlukan oleh organisme budidaya untuk proses respirasi. Berkurangnya kandungan oksigen terjadi akibat pemanfaatan oleh ikan untuk proses respirasi, metabolisme, termasuk pencernaan dan asimilasi makanan serta pertumbuhan menurut Effendi (2002). Kadar oksigen terlarut dalam air sangat penting bagi kelangsungan hidup semua organisme. Oksigen tergantung dari jenis ikan, umur dan aktifitasnya. 


\section{Kesimpulan dan Saran}

\section{A.Kesimpulan}

Kesimpulan penelitian ini adalah:

1. Pemberian vitamin D pada Daphnia sp. Berpengaruh nyata terhadap pertumbuhan ikan Tawes dengan dosis $25 \mathrm{mg} / \mathrm{L}$ menghasilkan bobot 245,1 $\mathrm{g}$ dan panjang 3,1 cm

2. Pengaruh penambahan dosis vitamin D pada Daphnia sp. untuk kelangsungan hidup larva ikan Tawes dapat diperoleh bahwa dosis $25 \mathrm{mg} / \mathrm{L}$ dengan nilai $\mathrm{SR}=85 \%$, sangat baik untuk pertumbuhan larva ikan Tawes, dan dosis $100 \mathrm{mg} / \mathrm{L}$ tanpa penambahan vitamin $\mathrm{D}$ nilai $\mathrm{SR}=$ $40 \%$, merupakan dosis yang tidak efektif.

\section{B.Saran}

1. Untuk meningkatkan kualitas pertumbuhan larva ikan Tawes (Puntius javanicus) dapat menggunakan kombinasi vitamin D dan Daphnia sp dengan dosis $25 \mathrm{mg} / \mathrm{L}$.

2. Penelitian mengenai efek Daphnia sp. yang dikombinasi vitamin D perlu diteliti lebih lanjut untuk memperoleh hasil yang terbaik.

\section{Daftar Pustaka}

Aquarista,F,Ujang Subhan,dan Iskandar, 2012. Pemberian Probiotik dengan Carrier Seolit pada Pembesaran Ikan Lele Dumbo (Clarias gariepinus), Jurnal Perikanan dan Kelautan,3(4): 133-140.

Cahyono,B.2011.Untung Berlipat Budi Daya Tawes Sebagai Bahan Baku Keripik.Lili Publisher, Yogyakarta. 110hal.

Effendi, I. 2002. Pengantar Akuakultur. PenebarSwadaya. Jakarta.185 hal.

Herawati, Hutabarat, J.dan Rajasa,O.2012. Effectof Using Guillard and W alne Technical Culture M edia on Growth an Fatty Acid Profilesof M icroalgae Skeletonema sp.in M ass Culture.J. Coast.Dev.

Imanuel,T.Herdiman,H.danW argasetia,T. 2015. Suplementasi Vitamin D Dosis Tinggi Menurunkan Kalsifikasi Tulang Femur Pada Janin Mencit. Jurnal Kedokteran Brawijaya. 2015.

Karyati, D. 2017. PeningkatanPertumbuhan Larva Ikan Gurame Yang Diberi Cacing Sutra Yang Dikombinasi Vitamin D. Skripsi Fakultas Ilmu Perikanan dan Kelutan, Universitas Satya Negara Indonesia.

Kottelat, M .,A.J.W hitten,S.N.Kartikasari \& S.W iroatmodjo.1993.Freshwater Fishes of W estern Indonesia and Sulawesi. Edisi Dwi Bahasa InggrisIndonesia.Periplus Edition (HK) Ltd. Bekerjasama dengan Kantor M enteriKLH,Jakarta. 
Lesmana,D.S.2004.Kualitas Air untuk Ikan Hias Air Tawar. Penebar Swadaya. Jakarta.

Ningsih, I. 2016. Peninigkatan Kualitas Pertumbuhan Larva Patin Yang di Suplementasi Vitamin D Pada Artemia. Skripsi Fakultas Ilmu Perikanan dan Kelutan, Universitas Satya Negara Indonesia.

Nirmala, K. dan Rasmawan. 2010. Kinerja Pertumbuhan Ikan Gurame (Osphronemus gouramy Lac.) yang Dipelihara pada M edia Bersalinitas dengan Paparan M edan Listrik,Jurnal Akuakultur Indonesia 9 (1):46-55.

Prasetyarini,P.2011.pengunaan pakan organik ternak, FKIP UM P. Program Studi Pendidikan Biologi, Universitas M uhamadiahPurwokerto.

Prastya,W . Dewiyanti,I.dan Ridwan,T. 2016.Program StudiBudidaya Perairan Fakultas Kelautan dan Perikanan Universitas Syiah Kuala Darussalam, Banda Aceh.Balai Perikanan Budidaya AirPayau (BPBAP), Aceh Besar. Jurnal Ilmiah M ahasiswa Kelautan dan Perikanan Unsyiah Volume1,nomor 1:55-65Januari-April2016.

Priyambodo, 2001. Budidaya Pakan Alami Untuk Ikan. Jakarta: Penerbit PT. Penebar Swadaya:hlm.28.Riede,K. 2004 Global register of migratory species - from global to regional scales. Final Report of the R\&D-Projekt 80805 081. Federal Agency for Nature Conservation.

SubandiyonodanS.Hastuti.2010.Lembaga Pengembangan dan Penjaminan M utu Pendidikan Universitas Diponegoro, Semarang.

Susanto. 2000. Usaha pembenihan dan pembesaran tawes.Penebar Swadaya. Jakarta.

Susanto, H. 2000. Budidaya Ikan Koi. Penebar Swadaya. Jakarta.107 hal.

Suwarsito dan Purbomantono C, 2016. Pengaruh Pemberian Kombinasi Pakan Alami Daphnia Dengan Kuning Telur Ayam Terhadap Pertumbuhan dan Sintasan Larva Ikan Koi. Skripsi Fakultas Keguruan dan Ilmu Pendidikan, Universitas M uhammadiah Purwokerto.

Tampubolon, E.H. 2015. Pengaruh Pemberian Pakan Alami Berbeda Terhadap Pertumbuhan dan Kelulushidupan Larva Ikan Betok (Anabas testudinieus). Skripsi. Fakultas PerikanandanIlmuKelautanUniversitas Riau.Pekanbaru

Zonneveld, N. Huisman, E.A., dan J.H. Boon.1991.Prinsip-prinsip Budidaya 